\title{
EVIDENCE FOR CHLORDECONE-STIMULATED OXIDATIVE STRESS IN DIFFERENT TISSUES OF THE CICHLID FISH, Pseudetroplus maculatus (Bloch, 1795)
}

\author{
Kunimmal Poothaadammal Asifa, Kumari Chidambaran Chitra* \\ Endocrinology and Toxicology Laboratory, Department of Zoology, University of Calicut, Malappuram District, \\ Kerala, India
}

*Corresponding Author, Email: kcchitra@yahoo.com

\begin{tabular}{l}
\hline ARTICLE INFO \\
\hline Received: 3 February 2017 \\
Received in revised form: 10 February \\
2017 \\
Accepted: 9 March 2017 \\
Available online: 23 March 2017
\end{tabular}

Keywords:

Chlordecone

Gill

Liver

Brain

Oxidative stress

\begin{abstract}
The present study was designed to assess the effect of chlordecone on the stimulation of oxidative stress in gill, liver and brain tissues of the cichlid fish, Pseudetroplus maculatus. Fishes were exposed to chlordecone at two sublethal concentrations, 3.5 and $7 \mu \mathrm{g} / \mathrm{L}$, for 24,72 and $96 \mathrm{~h}$, maintaining ten animals in each group. Chlordecone treatment did not alter the body weight of the animal. However, significant increase in the secretion of mucous and decrease in the weights of gill, brain and hepatosomatic index were observed at $7 \mu \mathrm{g} / \mathrm{L}$ of chlordecone treatment only after 96 h. Gill tissue showed significant increase in the activities of superoxide dismutase, catalase and glutathione reductase along with elevated levels of hydrogen peroxide and lipid peroxidation in concentration and timedependent manner. This could be the defensive mechanism of gill tissue to escape the toxic effects of chlordecone. In the liver tissue, superoxide dismutase activity was increased by $39 \%$ at $3.5 \mu \mathrm{g} / \mathrm{L}$ and by $73 \%$ at $7 \mu \mathrm{g} / \mathrm{L}$ of chlordecone treatment. Activities of catalase and glutathione reductase were decreased 3 to 9 times at 3.5 and $7 \mu \mathrm{g} / \mathrm{L}$ concentrations, respectively, with concomitant increase in hydrogen peroxide generation (17 to 28 times) and lipid peroxidation ( 3 to 7 times) at the end of $96 \mathrm{~h}$, which reveals the failure of hepatic antioxidant system to prevent free radical generation owing to chlordecone exposure. Activities of all antioxidant enzymes in the brain were inhibited by 29 to $80 \%$ along with the induction of hydrogen peroxide ( 13 to 20 times) and lipid peroxidation (6 to 11 times), thereby indicating imbalance in the antioxidant status. Activities of gill and liver marker enzyme - alkaline phosphatase - and acetylcholinesterase in brain were decreased. Therefore, imbalance in the antioxidant defence system as a result of chlordecone toxicity could lead to susceptible oxidative stress in various tissues of the fish.
\end{abstract}

\section{How to Cite}

Asifa, K. P., Chitra, K. C. (2017): Evidence for chlordecone-stimulated oxidative stress in different tissues of the cichlid fish, Pseudetroplus maculatus (Bloch, 1795). Croatian Journal of Fisheries, 75, 67-76. DOI: 10.1515/cjf-2017-0010. 


\section{INTRODUCTION}

Fish and the aquatic ecosystems, including ponds, lakes, rivers, streams and oceans, provide direct commercial benefit and indirect recreational values particularly to humans. Various agricultural and anthropogenic activities dispose a wide variety of toxic chemicals continuously into the aquatic ecosystems. Among these, pesticides are persistent contaminants due to their unregulated and indiscriminate applications. Pesticides or chemicals originating from agricultural activity find their path into the aquatic environment through runoff, atmospheric deposition or leaching through rainfall (Sitaramaraju et al., 2014). Therefore, pesticide contamination is one of the major causes of aquatic pollution, which has a profound effect on aquatic life and water quality.

Both commonly used pesticides as well as pesticides that are banned from the market years ago due to their quick fat solubility and bioaccumulation potential reach and accumulate in aquatic ecosystems thereby causing severe health hazards to all non-target aquatic organisms, including fish (Agrawal et al., 2010). Toxic effects of several pesticides in different fishes were reported worldwide and have been shown to cause a wide range of effects including behavioural modifications, oxidative damage, endocrine disruption and inhibition of acetylcholineesterase activity, developmental changes, histopathological alterations, genotoxicity and carcinogenicity (Murthy et al., 2013). The toxicity of any contaminant is dependent on the concentration of target receptor in the organism or the concentration of toxicant that reaches the organism. The absorption of toxicant by the organism depends on the shape, characteristics of the external covering of organisms, feeding behaviour, respiratory system, etc. (Landrum and Fisher, 1999). Thus the mode of action of pesticides varies among different organisms depending on the accumulation and persistence nature of the exposed compound.

Chlordecone is one of the synthetic organochlorine pesticides, first manufactured in the early 1950s and introduced commercially in the United States in 1958 under the trade name of Kepone. It has been used extensively in banana cultivation against banana root borer, as a miticide against rust mites on non-fruit bearing citrus trees, as a fungicide against apple scab and powdery mildew. Chlordecone is also used for the control of wire worms in potato and tobacco fields as well as to control slugs, snails and fire ants in ornamental shrubs, and is used in household products such as ant and roach traps (ATSDR, 1995). Based on the physico-chemical properties, it has been reported that chlordecone can be transported for long distances in the environment, either dissolved or bound to soil particles (UNEP, 2007). Chlordecone is resistant to degradation in the environment and possesses great potential of bioaccumulation and bioconcentration in fishes and other aquatic organisms (ATSDR, 1995). When chlordecone is released into water, it readily adsorbs to sediment where its half-life in river has been estimated as 3.8 to 46 years. Bioaccumulation is a process in which the toxicant gets absorbed in fish primarily due to the inability to excrete necessary levels of contaminant leading to ecological damage (Arnot and Gobas, 2006). Chlordecone has been shown to bioaccumulate in fish and crustaceans such as oysters, mysids and grass shrimp where the bioconcentration level varies depending on the species and duration of exposure (Bahner et al., 1977). Chlordecone has been shown to bioaccumulate and interrupt the molting process by decreasing the concentration of 20-hydroxyecdysone and the chitobiase activity in Macrobrachium rosenbergii (Lafontaine et al., 2016). Chlordecone has also shown to cause endocrine disruption by showing similarities to estrogen receptors and cytochrome $\mathrm{P} 450$ where it increased vitellogenin in females, degenerated gonads and increased the concentrations of plasma estradiol in both male and female rare minnow (Yang et al., 2016).

Fish are the final chain in an aquatic food web and an important food source for humans, so the exposure of chlordecone can be transferred into humans through the food chain. Chlordecone has been shown to cross placenta with a maximum concentration of 3.5 and $4.0 \mathrm{ppm}$ and the highest level of the toxicant has been reported in the liver of foetus, which was 4 to 5 times lower than the maternal concentration indicating the retarded distribution of chlordecone to the foetus (Kavlock et al., 1980). The median lethal concentration of chlordecone for $96 \mathrm{~h}$ has been determined in Etroplus maculatus as $35 \mu \mathrm{g} / \mathrm{L}$ (Asifa and Chitra, 2015). It has been shown to cause oxidative imbalance at sublethal concentration in the muscle tissue of Etroplus maculatus (Asifa et al., 2016a) and has been shown to induce the formation of micronucleus and other nuclear abnormalities such as blebbed, notched, lobed and irregular nuclei in the fish (Asifa et al., 2016b). Chlordecone at $0.35 \mu \mathrm{g} / \mathrm{L}$ concentration induced oxidative stress and tissue damage in the gill and liver of fish (Asifa et al., 2014). Therefore, fish are particularly threatened by the exposure to such aquatic contaminants and the practical use of the oxidative stress markers as bioindicators for environmental toxicology studies receives great attention in recent years.

Oxidative stress is a condition of a cell or tissue that transiently or chronically enhance the steady state of reactive oxygen species (ROS) production thereby disturbing cellular metabolism and its regulation and damaging cellular constituents (Lushchak, 2011). Oxidative stress biomarkers and antioxidant defences are excellent diagnostic and prognostic tools for assessing the effects of contaminants in aquatic organisms, especially fishes (Wilhelm, 1996). Sublethal concentrations of carbamazepine has been shown to cause severe oxidative damage in the brain of rainbow trout (Li et al., 2010) and contamination of several metals in aquatic ecosystem has been known to contribute to 
the induction of oxidative stress in fishes (Sevcikova et al., 2011). Pollutant-mediated mechanism of toxicity can be measured using intoxication and detoxication processes in exposed animals. In fish, waterborne pollutants can easily enter their body primarily through gills and pharynx. Liver is considered as the primary defensive organ of detoxification and the majority of the toxicant exerts toxicity by inhibiting cholinesterase activity in brain tissue and function as neurotoxic (Hayat et al., 2014). Thus, the present study was designed to assess the sublethal toxicity effect of chlordecone in the gill, liver and brain tissues of the cichlid fish, Pseudetroplus maculatus.

\section{MATERIALS AND METHODS}

\section{Experimental animal:}

Adult indigenous freshwater cichlid fish, Pseudetroplus maculatus, weighing $7 \pm 1 \mathrm{~g}$ and $7 \pm 1.5 \mathrm{~cm}$ in length were collected from KKF Nursery, Manjeri, Vaniyambalam, Kerala, India. Fishes were brought to the laboratory with least disturbance and were acclimatized to the laboratory conditions for 15 days prior to experiments. They were maintained in dechlorinated, well-aerated aquarium tanks (40 L capacity) and the health status of the animal was continuously monitored throughout the experiment.

The physico-chemical features of the tap water were estimated as per APHA (1998). Regularly monitored using standardized procedures were the following: water temperature in the test ranged from $28 \pm 2{ }^{\circ} \mathrm{C}$ during the experiment; oxygen saturation of water ranged between 70 and $100 \%$; $\mathrm{pH}$ was from 6.5 to 7.5 .

\section{Chemicals}

Technical grade organochloride pesticide, chlordecone (Kepone, decachlorooctahydro-1,3,4-metheno-2Hcyclobuta[cd]-pentalen-2-one, 99.9\% purity) was obtained from Supelco, USA. Malondialdehyde, NADPH, glutathione oxidized, thiobarbituric acid, pyrogallol, horse radish peroxidise, acetylthiocholine iodide (ATC), 5,5'-dithiobis2-dinitrobenzoic acid (DTNB) were obtained from Himedia Laboratories, Mumbai, India. All other chemicals were of analytical grade and obtained from local commercial sources.

\section{Treatment}

Chlordecone was dissolved in 1\% DMSO (dimethyl sulfoxide), which was used as control (vehicle) in the experiment. The median lethal concentration value of chlordecone for $96 \mathrm{~h}$ ( $\mathrm{LC}_{50}-96 \mathrm{~h}$ ) of Pseudetroplus maculatus was determined as $35 \mu \mathrm{g} / \mathrm{L}$ (Asifa and Chitra, 2015) by probit analysis. In the present study based on the $\mathrm{LC}_{50}-96 \mathrm{~h}$ value, two sublethal concentrations $-3.5 \mu \mathrm{g} / \mathrm{L}$ and $7 \mu \mathrm{g} / \mathrm{L}\left(1 / 10^{\text {th }}\right.$ and $1 / 5^{\text {th }}$ of $\mathrm{LC}_{50}$ ) - were exposed for three durations - 24, 72 and 96 h. After acclimatization, fishes were grouped into various groups in different tanks by maintaining ten animals per group.

Group I - Solvent-free control; Group II - Solvent control ( $1 \%$ DMSO)

Chlordecone-treatment: Group III (3.5 $\mu \mathrm{g} / \mathrm{L})$ for 24, 72 and $96 \mathrm{~h}$, respectively; and Group IV ( $7 \mu \mathrm{g} / \mathrm{L}$ ) maintained for 24 , 72 and $96 \mathrm{~h}$, respectively.

At the end of every treatment period, fishes were caught very gently using a small dip net, one at a time with least disturbance, sacrificed for dissecting gill, liver and brain tissues for further analysis.

\section{Preparation of tissue homogenates and biochemical analysis}

Gill, liver and brain tissues were cleaned from mucous and blood and stored at $4^{\circ} \mathrm{C}$ until biochemical analyses were performed. $1 \%(\mathrm{w} / \mathrm{v})$ homogenate of selected tissues were prepared in ice-cold normal saline with the help of a motordriven glass Teflon homogenizer on crushed ice for a minute. The homogenate was centrifuged at $8000 \mathrm{~g}$ for $15 \mathrm{~min}$ at $4^{\circ} \mathrm{C}$ to obtain the supernatant, which was then used for the biochemical analyses.

In supernatant of crude tissue homogenates, protein was estimated by the method of Lowry et al. (1951) with BSA as the standard. Activities of superoxide dismutase - EC 1.15.1.1 (Marklund and Marklund, 1974), catalase - EC. 1.11.1.6 (Claiborne, 1985), glutathione reductase - EC. 1.6.4.2 (Carlberg and Mannervik, 1985), level of hydrogen peroxide generation (Pick and Keisari, 1981), level of lipid peroxidation (Ohkawa et al., 1979), activities of alkaline phosphatase - EC.3.1.3.1 (Bessey et al., 1946) and acetylcholinesterase - EC. 3.1.1.7 (Ellman et al., 1961) were measured.

\section{Statistical analysis}

Statistical analyses were performed using a one-way analysis of variance (ANOVA) followed by Duncan's Multiple Range Test using statistical package SPSS 19.0. Differences were considered to be significant at $p<0.05$ against control groups. Data are presented as mean \pm SD for ten animals per group. All biochemical estimations were carried out in duplicates.

\section{RESULTS}

In the present study, fishes exposed to $1 \%$ DMSO (solvent control) did not show significant variations in any parameters including body weights, organ weight and other biochemical 
parameters, when compared with the negative control group (Fig. 1 and 2; Table 1-3).
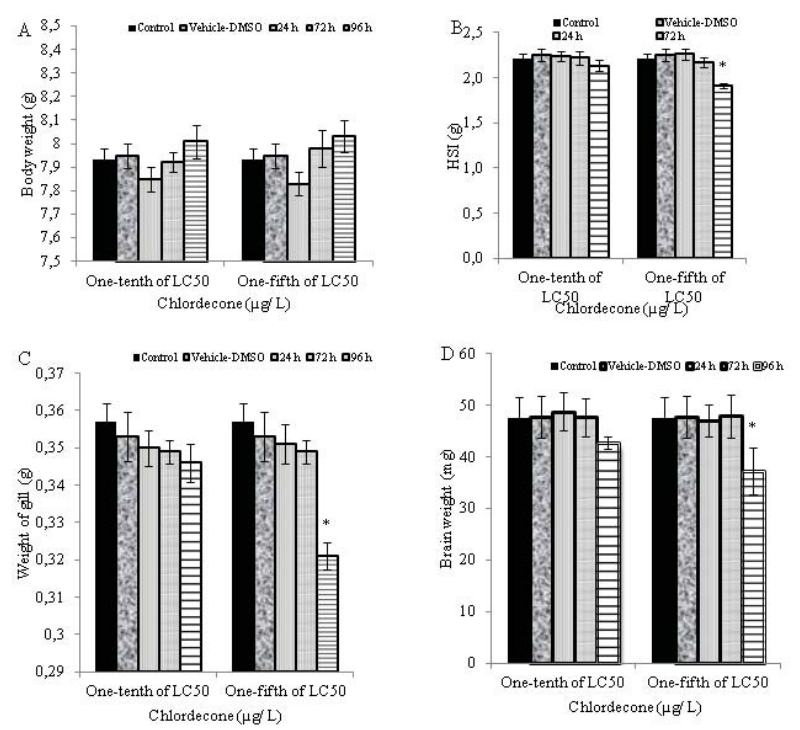

Fig 1.Effect of chlordecone on A) body weight; B) hepatosomatic index; C) weight of gill; D) weight of brain in Pseudetroplus maculatus

Mean \pm SD; $n=10$ animals/ group; * significant at $\mathrm{P}<0.05$

Chlordecone exposure showed no significant change in the body weight of fish at both sublethal concentrations when compared with the control groups (Fig. 1A). The hepatosomatic index as well as weight of gill and brain were decreased (Fig. 1B-1D), while mucous secretion was increased significantly after $96 \mathrm{~h}$ to a higher concentration of chlordecone (Fig. 2).
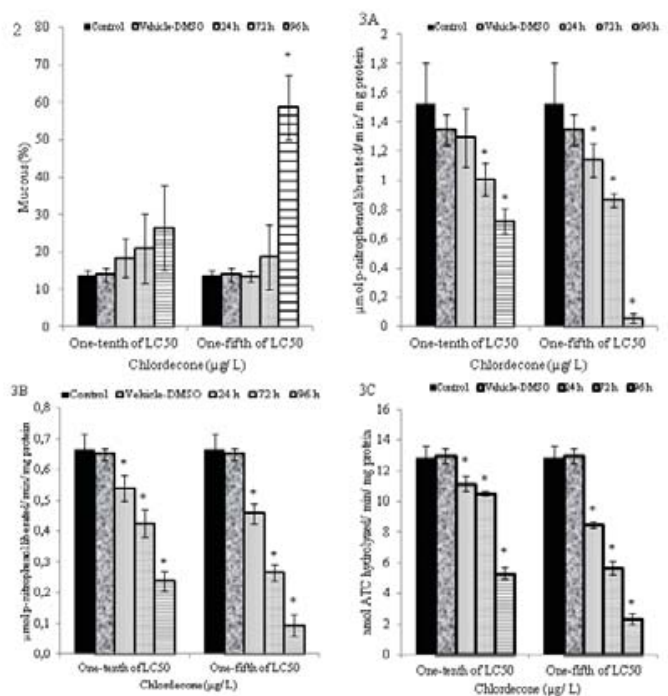

Fig 1.Effect of chlordecone on A) mucous deposition; B) activity of alkaline phosphatase in gill; C) activity of alkaline phosphatase in liver; D) activity of acetylcholinesterase in the brain of Pseudetroplus maculatus

Mean $\pm \mathrm{SD} ; \mathrm{n}=10$ animals $/$ group; ${ }^{*}$ significant at $\mathrm{P}<0.05$
In gill tissue, chlordecone at both sublethal concentrations showed an increase in the activities of superoxide dismutase, catalase and glutathione reductase in concentrationdependent manner when compared to the corresponding control groups (Table 1).

The levels of hydrogen peroxide generation and lipid peroxidation were significantly higher in the gill tissue at both concentrations than that of the control groups (Table 1 ). In the liver tissue, activity of superoxide dismutase was increased whereas the activities of other antioxidant enzymes such as catalase and glutathione reductase decreased with a concomitant increase in hydrogen peroxide generation and lipid peroxidation (Table 2).

The marker enzyme, alkaline phosphatase significantly decreased in a concentration-dependent and timedependent manner in both gill and liver tissues after chlordecone treatment when compared to the control groups (Figure 2B and $2 \mathrm{C}$ ). In brain tissue, a significant decrease in the activities of all antioxidant enzymes along with significant $(\mathrm{P}<0.05)$ increase in the levels of hydrogen peroxide and lipid peroxidation were observed (Table 3).

The activity of acetylcholinesterase enzyme in brain showed concentration and time-dependent decrease when compared to the control groups (Figure 2D).

\section{DISCUSSION}

Animals, when exposed to stress conditions or pollutants, may either overcome the threat of environmental stressors or they may develop pathological conditions which alter the normal functioning of the body. The present study evaluates the toxic effects induced by chlordecone by targeting the stimulation of reactive oxygen species production in vital organs - gill, liver and brain tissues of Pseudetroplus maculatus.

Chlordecone exposure did not alter the body weight of animals and this reflects that chlordecone exposure did not induce anorexia or affect food consumption in exposed fish. The weights of gill, brain and the hepatosomatic index decreased at the end of $96 \mathrm{~h}$ only at one-fifth of $\mathrm{LC}_{50}$ concentration and no notable changes were observed in othergroups. However, a time-dependent increase in mucous deposition was seen at both concentrations of treatment, while a notable significant $(P<0.05)$ increase by $60 \%$ of mucous deposition was observed at higher concentrations after $96 \mathrm{~h}$ of treatment, when compared with the control groups. Hypersecretion of mucous is the first line of defence that helps reduce the adverse effects of toxicant (Mishra and Poddar, 2014). Mucous secretion cleans the respiratory surfaces facilitating the removal of trapped toxicants in gill or skin (Chandra and Banerjee, 2004). A similar observation has been reported when the nanoparticles of silicon dioxide were exposed to freshwater fish, Oreochromis mossambicus (Vidya and Chitra, 2015). 
Table 1. Effect of chlordecone on the activities of antioxidant enzymes and levels of hydrogen peroxide and lipid peroxidation in gill of cichlid fish, Pseudetroplus maculatus

\begin{tabular}{|c|c|c|c|c|c|c|c|c|}
\hline \multirow{2}{*}{ Parameters } & \multirow{2}{*}{ Control } & \multirow{2}{*}{ DMSO } & \multicolumn{3}{|c|}{ 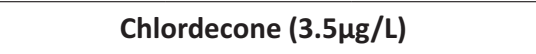 } & \multicolumn{3}{|c|}{ Chlordecone $(7 \mu \mathrm{g} / \mathrm{L})$} \\
\hline & & & $24 \mathrm{~h}$ & $72 \mathrm{~h}$ & $96 \mathrm{~h}$ & $24 \mathrm{~h}$ & $72 \mathrm{~h}$ & $96 \mathrm{~h}$ \\
\hline SOD ${ }^{a}$ & $6.96 \pm 0.240$ & $7.15 \pm 0.351$ & $7.98 \pm 0.30$ & $8.88 \pm .26^{*}$ & $9.64 \pm 0.31 *$ & $8.33 \pm 0.44$ & $9.57 \pm 0.33^{*}$ & $12.32 \pm 0.35 *$ \\
\hline $\mathrm{CAT}^{\mathrm{b}}$ & $6.27 \pm 0.303$ & $6.51 \pm 0.46$ & $7.47 \pm 0.48$ & $7.52 \pm 0.29$ & $8.8 \pm 0.12^{*}$ & $7.31 \pm 0.44$ & $8.45 \pm 0.35 *$ & $10.21 \pm 0.36^{*}$ \\
\hline $\mathbf{G R}^{\mathrm{c}}$ & $6.15 \pm 0.284$ & $6.29 \pm 0.45$ & $6.81 \pm 0.24$ & $8.37 \pm 0.39 *$ & $10.07 \pm 0.38 *$ & $6.53 \pm 0.33$ & $4.68 \pm 0.29$ & $10.89 \pm 0.71 *$ \\
\hline $\mathrm{H}_{2} \mathrm{O}_{2}{ }^{d}$ & $0.07 \pm 0.007$ & $0.07 \pm 0.004$ & $0.09 \pm 0.02$ & $0.16 \pm 0.007$ & $0.81 \pm 0.05 *$ & $0.15 \pm 0.03$ & $0.57 \pm 0.04 *$ & $1.95 \pm 0.13^{*}$ \\
\hline LPx ${ }^{e}$ & $2.94 \pm 0.531$ & $2.58 \pm 0.325$ & $4.08 \pm 0.14$ & $4.85 \pm 0.19$ & $7.20 \pm 0.26 *$ & $4.15 \pm 0.50$ & $6.69 \pm 0.27 *$ & $11.93 \pm 0.55^{*}$ \\
\hline
\end{tabular}

a $\mathrm{nmol}$ pyrogallol oxidized/ $\mathrm{min} / \mathrm{mg}$ protein; ${ }^{\mathrm{b}} \mu \mathrm{mol} \mathrm{H}_{2} \mathrm{O}_{2}$ consumed/ $\mathrm{min} / \mathrm{mg}$ protein; ${ }^{\mathrm{c}} \mathrm{nmol} \mathrm{NADPH}$ oxidized/ min/ mg protein; ${ }^{\mathrm{d}} \mathrm{nmol}$ $\mathrm{H}_{2} \mathrm{O}_{2}$ produced/ min/ mg protein; ${ }^{e} \mu \mathrm{mol}$ malondialdehyde produced/ mg protein; mean $\pm \mathrm{SD} ; \mathrm{n}=10$ animals $/$ group; * significant at $\mathrm{P}<0.05$

Table 2. Effect of chlordecone on the activities of antioxidant enzymes and levels of hydrogen peroxide and lipid peroxidation in liver of cichlid fish, Pseudetroplus maculatus

\begin{tabular}{|c|c|c|c|c|c|c|c|c|}
\hline \multirow{2}{*}{ Parameters } & \multirow{2}{*}{ Control } & \multirow{2}{*}{ DMSO } & \multicolumn{3}{|c|}{ Chlordecone $(3.5 \mu \mathrm{g} / \mathrm{L})$} & \multicolumn{3}{|c|}{ Chlordecone $(7 \mu \mathrm{g} / \mathrm{L})$} \\
\hline & & & $24 \mathrm{~h}$ & $72 \mathrm{~h}$ & $96 \mathrm{~h}$ & $24 \mathrm{~h}$ & $72 \mathrm{~h}$ & $96 \mathrm{~h}$ \\
\hline SOD ${ }^{a}$ & $\begin{array}{l}6.24 \pm \\
0.139\end{array}$ & $\begin{array}{l}6.60 \pm \\
0.144\end{array}$ & $\begin{array}{l}7.01 \pm \\
0.356\end{array}$ & $\begin{array}{l}7.50 \pm \\
0.156\end{array}$ & $\begin{array}{l}8.66 \pm \\
0.427^{*}\end{array}$ & $\begin{array}{l}6.76 \pm \\
0.546\end{array}$ & $\begin{array}{c}7.81 \pm \\
0.183^{*}\end{array}$ & $\begin{array}{l}10.81 \pm \\
0.588^{*}\end{array}$ \\
\hline $\mathrm{CAT}^{\mathrm{b}}$ & $\begin{array}{l}9.00 \pm \\
0.517\end{array}$ & $\begin{array}{l}8.73 \pm \\
0.362\end{array}$ & $\begin{array}{c}7.13 \pm \\
0.362^{*}\end{array}$ & $\begin{array}{c}6.17 \pm \\
0.356^{*}\end{array}$ & $\begin{array}{l}2.87 \pm \\
0.364^{*}\end{array}$ & $\begin{array}{c}7.28 \pm \\
0.486^{*}\end{array}$ & $\begin{array}{l}4.51 \pm \\
0.521^{*}\end{array}$ & $\begin{array}{c}1.31 \pm \\
0.296 *\end{array}$ \\
\hline $\mathbf{G R}^{\mathrm{c}}$ & $\begin{array}{l}8.65 \pm \\
0.606\end{array}$ & $\begin{array}{l}8.99 \pm \\
0.314\end{array}$ & $\begin{array}{l}7.88 \pm \\
0.486\end{array}$ & $\begin{array}{l}5.59 \pm \\
0.405^{*}\end{array}$ & $\begin{array}{l}3.24 \pm \\
0.415^{*}\end{array}$ & $\begin{array}{c}6.30 \pm \\
0.283^{*}\end{array}$ & $\begin{array}{c}3.77 \pm \\
0.542^{*}\end{array}$ & $\begin{array}{c}1.43 \pm \\
0.437^{*}\end{array}$ \\
\hline $\mathrm{H}_{2} \mathrm{O}_{2}{ }^{d}$ & $\begin{array}{l}0.28 \pm \\
0.002\end{array}$ & $\begin{array}{l}0.26 \pm \\
0.005\end{array}$ & $\begin{array}{l}0.22 \pm \\
0.050\end{array}$ & $\begin{array}{l}0.78 \pm \\
0.052\end{array}$ & $\begin{array}{l}4.79 \pm \\
0.593^{*}\end{array}$ & $\begin{array}{l}0.49 \pm \\
0.037\end{array}$ & $\begin{array}{c}2.17 \pm \\
0.606^{*}\end{array}$ & $\begin{array}{l}7.93 \pm \\
0.602 *\end{array}$ \\
\hline LPx ${ }^{e}$ & $\begin{array}{l}1.65 \pm \\
0.113\end{array}$ & $\begin{array}{l}1.94 \pm \\
0.121\end{array}$ & $\begin{array}{l}2.24 \pm \\
0.446\end{array}$ & $\begin{array}{l}4.84 \pm \\
0.639 *\end{array}$ & $\begin{array}{c}9.09 \pm \\
0.592^{*}\end{array}$ & $\begin{array}{l}4.36 \pm \\
0.263^{*}\end{array}$ & $\begin{array}{l}7.16 \pm \\
0.538 *\end{array}$ & $\begin{array}{c}11.94 \pm \\
0.696^{*}\end{array}$ \\
\hline
\end{tabular}

a $\mathrm{nmol}$ pyrogallol oxidized/ $\mathrm{min} / \mathrm{mg}$ protein; ${ }^{\mathrm{b}} \mu \mathrm{mol} \mathrm{H}_{2} \mathrm{O}_{2}$ consumed/ $\mathrm{min} / \mathrm{mg}$ protein; ${ }^{\mathrm{c}} \mathrm{nmol} \mathrm{NADPH}$ oxidized/ $\mathrm{min} / \mathrm{mg} \mathrm{protein} ;{ }^{\mathrm{d}} \mathrm{nmol}$ $\mathrm{H}_{2} \mathrm{O}_{2}$ produced/ min/ mg protein; ${ }^{\mathrm{e}} \mu \mathrm{mol}$ malondialdehyde produced/ mg protein; mean $\pm \mathrm{SD} ; \mathrm{n}=10$ animals/ group; ${ }^{*}$ significant at $\mathrm{P}<0.05$

Table 3. Effect of chlordecone on the activities of antioxidant enzymes and levels of hydrogen peroxide and lipid peroxidation in the brain of cichlid fish, Pseudetroplus maculatus

\begin{tabular}{|c|c|c|c|c|c|c|c|c|}
\hline \multirow[b]{2}{*}{ Parameters } & \multirow[b]{2}{*}{ Control } & \multirow[b]{2}{*}{ DMSO } & \multicolumn{3}{|c|}{ Chlordecone $(3.5 \mu \mathrm{g} / \mathrm{L})$} & \multicolumn{3}{|c|}{ Chlordecone $(7 \mu \mathrm{g} / \mathrm{L})$} \\
\hline & & & $24 \mathrm{~h}$ & $72 \mathrm{~h}$ & $96 \mathrm{~h}$ & $24 \mathrm{~h}$ & $72 \mathrm{~h}$ & $96 \mathrm{~h}$ \\
\hline SOD $^{a}$ & $\begin{array}{l}7.8 \pm \\
0.313\end{array}$ & $\begin{array}{l}7.91 \pm \\
0.483\end{array}$ & $\begin{array}{c}6.84 \pm \\
0.498^{*}\end{array}$ & $\begin{array}{c}6.05 \pm \\
0.479 *\end{array}$ & $\begin{array}{c}3.05 \pm \\
0.623^{*}\end{array}$ & $\begin{array}{c}3.02 \pm \\
0.478 *\end{array}$ & $\begin{array}{c}2.44 \pm \\
0.264 *\end{array}$ & $\begin{array}{c}1.58 \pm \\
0.348^{*}\end{array}$ \\
\hline CAT $^{b}$ & $\begin{array}{l}7.42 \pm \\
0.331\end{array}$ & $\begin{array}{l}7.43 \pm \\
0.177\end{array}$ & $\begin{array}{l}7.78 \pm \\
0.574\end{array}$ & $\begin{array}{c}9.20 \pm \\
0.471^{*}\end{array}$ & $\begin{array}{l}11.35 \pm \\
0.305^{*}\end{array}$ & $\begin{array}{c}5.56 \pm \\
0.261^{*}\end{array}$ & $\begin{array}{c}5.08 \pm \\
0.171^{*}\end{array}$ & $\begin{array}{c}1.35 \pm \\
0.243^{*}\end{array}$ \\
\hline $\mathbf{G R}^{\mathrm{c}}$ & $\begin{array}{l}9.08 \pm \\
0.308\end{array}$ & $\begin{array}{l}9.10 \pm \\
0.301\end{array}$ & $\begin{array}{l}8.42 \pm \\
0.248\end{array}$ & $\begin{array}{c}7.32 \pm \\
0.280 *\end{array}$ & $\begin{array}{c}6.44 \pm \\
0.174 *\end{array}$ & $\begin{array}{l}8.35 \pm \\
0.231\end{array}$ & $\begin{array}{c}7.35 \pm \\
0.216^{*}\end{array}$ & $\begin{array}{c}2.58 \pm \\
0.209 *\end{array}$ \\
\hline $\mathrm{H}_{2} \mathrm{O}_{2}{ }^{d}$ & $\begin{array}{l}0.32 \pm \\
0.032\end{array}$ & $\begin{array}{l}0.34 \pm \\
0.022\end{array}$ & $\begin{array}{l}0.43 \pm \\
0.038\end{array}$ & $\begin{array}{l}1.02 \pm \\
0.117\end{array}$ & $\begin{array}{c}4.50 \pm \\
0.436^{*}\end{array}$ & $\begin{array}{l}0.76 \pm \\
0.054\end{array}$ & $\begin{array}{c}1.84 \pm \\
0.440^{*}\end{array}$ & $\begin{array}{c}6.69 \pm \\
0.316^{*}\end{array}$ \\
\hline $\operatorname{LPx}^{\mathrm{e}}$ & $\begin{array}{l}1.63 \pm \\
0.366\end{array}$ & $\begin{array}{l}1.82 \pm \\
0.426\end{array}$ & $\begin{array}{l}3.29 \pm \\
0.424\end{array}$ & $\begin{array}{l}4.90 \pm \\
0.660^{*}\end{array}$ & $\begin{array}{l}10.54 \pm \\
0.290^{*}\end{array}$ & $\begin{array}{l}5.66 \pm \\
0.451^{*}\end{array}$ & $\begin{array}{c}8.90 \pm \\
0.521^{*}\end{array}$ & $\begin{array}{c}18.70 \pm \\
0.71 *\end{array}$ \\
\hline
\end{tabular}

${ }^{a}$ nmol pyrogallol oxidized/ min/ mg protein; ${ }^{b} \mu \mathrm{mol} \mathrm{H}_{2} \mathrm{O}_{2}$ consumed/ min/ $\mathrm{mg}$ protein ; ${ }^{\mathrm{c}} \mathrm{nmol} \mathrm{NADPH}$ oxidized/ min/ mg protein; ${ }^{\mathrm{d}} \mathrm{nmol}$ $\mathrm{H}_{2} \mathrm{O}_{2}$ produced/ min/ mg protein; ${ }^{\mathrm{e}} \mu \mathrm{mol}$ malondialdehyde produced/ $\mathrm{mg}$ protein; mean $\pm \mathrm{SD} ; \mathrm{n}=10$ animals $/$ group; * significant at $\mathrm{P}<0.05$ 
Environmental contaminants, when frequently released into the aquatic environment, adversely affect the habitat, its flora and fauna and have been shown to frequently activate the endogenous production of reactive oxygen species (ROS), which resulted in cellular oxidative damage. Therefore, there should be a critical balance between prooxidants and antioxidants in the biological system; if however disrupted, oxidative stress may be induced. Cellular oxidative damage is due to depletion of the activity of antioxidant enzymes or excessive accumulation of free radicals or both (Halliwell, 1995). ROS are molecules derived from oxygen that act as oxidants capable of damaging major biological macromolecules such as nucleic acids, proteins and membrane phospholipids, which could ultimately result in cellular pathologies and finally lead to cell death (Castro and Freeman, 2001). Normal cellular homeostasis of the production of ROS and protection of cells/ tissues from oxidative damage can be brought about by the powerful activation of endogenous antioxidant defence mechanisms. Primary defences against ROS production are brought about by the involvement of antioxidant enzymes, such as superoxide dismutase (SOD), catalase (CAT), glutathione reductase (GR) and glutathione peroxidise (GPx), which involves the enzymatic removal of ROS, whereas secondary defence is offered by natural free radical scavengers such as reduced glutathione, -tocopherol, ascorbate, etc. (Bandyopadhyay et al., 1999).

Superoxide $\left(\mathrm{O}_{2}^{-}\right)$is the parental form of intracellular reactive oxygen species, which is a highly reactive molecule, but it can be converted to $\mathrm{H}_{2} \mathrm{O}_{2}$ by the enzyme SOD and then to oxygen and water by enzymes such as CAT and GPx (Mates et al., 1999). GR is an enzyme responsible for the recycling of reduced glutathione, which is one of the most copious reducing thiols in majority of cells. Glutathione, in its reduced form, is involved in scavenging the endogenous production of cellular reactive oxygen species (Chang et al., 1978; Dorval and Hontela, 2003). Pesticides are known to act as prooxidants and have been shown to induce oxidative stress in aquatic animals, especially in fishes, by several ways such as decreasing the potential of antioxidant enzymes, exhausting the reserves of reductants like glutathione, entering into redox cycle, and ultimately by modifying translation and transcription processes (Lushchak, 2011). Some pollutants significantly accumulate in specific tissues without any toxic effects, while others exhibit high toxicity even at low levels and interfere with metabolic processes (Jaishankar et al., 2014). The present study was therefore designed to test the hypothesis that if the toxicant, chlordecone, is exposed to fish at two sublethal concentrations for short durations, it could stimulate the production of reactive oxygen species and thus lead to oxidative damage in various vital organs - gill, liver and brain of the freshwater fish, Pseudetroplus maculatus.

Gills are the first and major target of aquatic pollutants due to the continuous and constant contact with the external environment (Perry and Laurent, 1993). Gill performs multiple vital functions such as respiration, osmoregulation and excretion in fishes. In the present study, chlordecone exposure showed a significant increase in the activity of superoxide dismutase at both concentrations after 72 and $96 \mathrm{~h}$ of exposure. SOD catalyzes the biochemical reaction by destroying the free radical superoxide and converts it to hydrogen peroxide. Chlordecone treatment also increased the activity of catalase and glutathione reductase to detoxify and protect the gill tissue from hydrogen peroxide generation. However, failure of elimination of hydrogen peroxide was revealed by its significant increase followed by the increase in the level of lipid peroxidation in gill tissue. Therefore, intracellular condition of gill tissue preferred more pro-oxidant to normal condition when exposed to the toxicant. The present results clearly indicate that chlordecone treatment stimulated reactive oxygen species production in gill though it attempted an adaptive response to get rid of free radicals by increasing the activities of antioxidant enzymes. Similar results have been observed when fish is exposed to one of the estrogenic environmental pollutants, bisphenol A (Chitra and Sajitha, 2014).

Liver is considered as the main and important detoxifying organ in fish and often associated with metabolism, biotransformation and excretion of toxic compounds. Hepatotoxicity is therefore an important endpoint for assessing the toxic effects of pollutants, especially pesticides, in fishes (Patil and David, 2009). Several environmental risk factors, including alcohol, drugs, environmental pollutants and irradiation, may induce oxidative stress in liver, which in turn results in severe liver diseases (Li et al., 2015). The present observation showed a significant increase in the activity of SOD in hepatocytes after chlordecone exposure. This could be a defensive mechanism of hepatocytes to convert superoxide radical to hydrogen peroxide. The present result coincides with another study when atrazine exposed for 14 days increased the activity of SOD in the liver of zebra fish Danio rerio (Jin et al., 2010). However, the activities of catalase and glutathione reductase were decreased significantly in a time-dependent manner. The observation illustrates failure of the enzyme to remove hydrogen peroxide, which was evident by the 8-fold increase in the level of hydrogen peroxide. $\mathrm{H}_{2} \mathrm{O}_{2}$ generation thus leads to the induction of lipid peroxidation as revealed in the present study. Lipid peroxidation disrupts the membrane lipid bilayer arrangement that may inactivate membranebound receptors, enzymes along with an increase in tissue permeability (Halliwell and Gutteridge, 1999). Our previous findings have reported that $0.35 \mu \mathrm{g} / \mathrm{L}$ concentration of chlordecone decreased the activities of superoxide dismutase, catalase and glutathione reductase, and increased the levels of hydrogen peroxide generation and lipid peroxidation in gill and liver of fish (Asifa et al., 2014). Another study has reported that the exposure of sublethal concentrations of nonylphenol inhibited the activities of antioxidant enzymes and induced oxidative stress in the liver of fish (Asifa and Chitra, 2016a). 
Alkaline phosphatase is a stress marker enzyme that serves as a diagnostic tool for detecting toxicity stress of chemicals in various tissues such as gill, liver and muscle. The enzyme is mainly efficient in an alkaline environment, responsible for removing phosphate groups from molecules, such as nucleotides, proteins and alkaloids (Dyhrman and Palanik, 1999). Alkaline phosphatase is a hydrolytic lysosomal enzyme and is released by the lysosomes for the hydrolysis of foreign material. Alkaline phosphatase is also involved in the mediation of membrane transport and transphosphorylation. It is found in all cell membranes where active transport occurs, therefore, is frequently used to measure the integrity of the plasma membrane (Akanji et al., 1993). Subsequently the enzyme activity may begin to drop either as a result of having partly or fully encountered the toxin or as a result of cell damage. The present study showed concentration and timedependent decrease in the activity of alkaline phosphatase in both gill and liver tissue when exposed to chlordecone. The inhibition might be probably due to leakage of the enzyme from cytosol across the injured plasma membrane into the general blood circulation or decreased enzyme synthesis as a result of organ dysfunction, which could often lead to disturbed membrane transport and upset structural integrity of cells (Bakde and Poddar, 2011; Chitra and Maiby, 2014).

Brain is the principal organ which is highly rich in fatty acids, also an excellent consumer of high levels of energy and physiological oxygen but with poor antioxidant defence mechanisms, which makes it predominantly susceptible to oxidative stress (Migliore and Coppede, 2009). Chlordecone exposure caused a significant decrease in the activity of SOD and GR at both sublethal concentrations. But a significant induction of CAT activity was observed at lower concentrations of chlordecone after $96 \mathrm{~h}$ of treatment, and when the concentration increases - its activity declined in a time-dependent manner. Chlordecone exposure increased the levels of hydrogen peroxide and lipid peroxidation in brain tissue. In general, chlordecone exposure inhibits the activities of antioxidant enzymes and induced lipid peroxidation, which in turn causes generation of reactive oxygen species and oxidative damage to the brain tissue.

Acetylcholinesterase (AChE) activity is routinely employed as a biomarker of the exposure to certain groups of contaminants, especially pesticides. In the present study the activity of acetylcholinesterase in the brain showed a significant decrease at both sublethal concentrations in a time-dependent manner. Inhibition in AChE could lead to an accumulation of acetylcholine at central cholinergic synapses and neuromuscular junctions (Varo et al., 2003). Accordingly, nerves in the brain collapse, which leads to behavioural changes in fish. Such unusual behavioural changes associated with chlordecone exposure, such as slow movement and lethargy, hitting on the side walls, reddening of eyes and fins as well as exopthalmia, were observed in our laboratory (Asifa and Chitra, 2015). AChE-linked unusual behaviours (hyperactivity, vertical position and loss of equilibrium) were observed in Clarias batrachus when exposed to a fungicide, Trizole (Srivastava and Singh, 2014). Reduction in the activity of AChE in the brain tissue when exposed to toxicants such as bisphenol $\mathrm{A}$ and nonylphenol have been observed in Etroplus maculatus (Rejitha et al., 2016; Asifa and Chitra, 2016b).

\section{CONCLUSION}

In conclusion, the present study demonstrated the antioxidant responses owing to the exposure of chlordecone in various tissues such as gill, liver and brain of fish, Pseudetroplus maculatus. Though the levels of hydrogen peroxide generation and lipid peroxidation exhibited a concentration-dependent increase in all tissues, the toxicity of chlordecone varied among the tissues thereby inducing oxidative stress in the fish, Pseudetroplus maculatus.

\section{ACKNOWLEDGMENTS}

Authors gratefully acknowledge the financial grant from Kerala State Council for Science, Technology and Environment (KSCSTE), Thiruvananthapuram, Kerala, India to carry out this study.

\section{Sažetak}

\section{DOKAZ ZA KLORDEKONSKO POTICANJE OKSIDATIVNOG STRESA U RAZLIČITIM TKIVIMA CIKLIDA Pseudetroplus maculatus (Bloch, 1795)}

Ova studija je osmišljena kako bi se ocijenio učinak klordekona na poticanje oksidativnog stresa u tkivima škrga, jetre i mozga ciklidne vrste Pseudetroplus maculatus. Ribe su bile izložene klordekonu u dvjema kritičnim koncentracijama - 3,5 i 7 $\mu$ g / L - u trajanju od 24, 72 i 96 sati, s po deset životinja u svakoj grupi. Tretiranje klordekonom nije djelovalo na tjelesnu težinu riba. Međutim, značajan porast lučenja sluzi i smanjenje težine škrga, mozga i hepatosomatskog indeksa su zabilježeni kod tretiranja sa 7 gg / L klordekona već nakon 96 sati. U tkivu škrga utvrđen je značajan porast aktivnosti superoksid dismutaze, katalaze i glutation-reduktaze, zajedno s povišenim razinama vodikovog peroksida i lipidne peroksidacije, koji je ovisan o koncentraciji i vremenu. To bi mogao biti obrambeni mehanizam tkiva škrga kako bi se smanjio toksični učinak klordekona. U tkivu jetre, aktivnost superoksida dismutaze je povećana za $39 \%$ pri 3,5 $\mu \mathrm{g}$ / L, a za $73 \%$ pri $7 \mu \mathrm{g} / \mathrm{L}$ tretiranja klordekonom. Aktivnosti katalaze i glutation-reduktaze su smanjene za 3 do 9 puta pri koncentracijama 3,5 i $7 \mu \mathrm{g} / \mathrm{L}$, odnosno s istodobnim porastom vodikovog peroksida (17 do 28 puta) i lipidne peroksidacije (3 do 7 puta) na kraju 96 sati, što otkriva neuspjeh sustava jetrenog antioksidansa da spriječi nastajanje slobodnih radikala kod izloženosti klordekonu. 
Aktivnosti svih antioksidativnih enzima u mozgu su inhibirani od 29 do $80 \%$, uz indukciju vodikovog peroksida (13 do 20 puta) i lipidne peroksidacije (6 do 11 puta) što ukazuje na neravnotežu u antioksidativnom sustavu. Aktivnosti marker enzima škrga i jetre - alkalne fosfataze - i acetilkolinesteraze u mozgu bio je smanjen. Dakle, neravnoteža u antioksidativnom obrambenom sustavu kao posljedica toksičnosti klordekona može dovesti do podložnosti oksidativnom stresu u različitim tkivima riba.

Ključne riječi: klordekon, škrge, jetra, mozak, oksidativni stres

\section{REFERENCES}

Agency for Toxic Substances and Disease Registry (ATSDR) (1995): Toxicological profile for mirex and chlordecone. Atlanta, GA: U.S. Department of Health and Human Services, Public Health Service.

Agrawal, A., Pandey, R. S., Sharma, B. (2010): Water pollution with special reference to pesticide contamination in India. Journal of Water Resource and Protection, 2, 5, 432-448.

Akanji, M. A., Olagoke, O. A., Oloyede, O. B. (1993): Effect of chronic consumption of metabisulphite on the integrity of the kidney cellular system. Toxicology, 81, 3, 173-179.

American Public Health Association (APHA) (1998): Standard methods for the examination of water and wastewater, 20th Edition, Washington, DC.

Arnot, J. A., Gobas, F. A. P. C. (2006): A review of bioconcentration factor (BCF) and bioaccumulation factor (BAF) assessments for organic chemicals in aquatic organisms. Environmental Reviews, 14, 4, 257-297.

Asifa, K. P., Balakrishnan, V., Chitra, K. C. (2014): Toxicity evaluation of chlordecone and its effect on oxidative imbalance in the cichlid fish, Etroplus maculatus (Bloch). International Journal of Zoology and Research, 4, 2, 1-20.

Asifa, K. P., Chitra, K. C. (2015): Determination of median lethal concentration $\left(\mathrm{LC}_{50}\right)$ and behavioral effects of chlordecone in the cichlid fish, Etroplus maculatus. International Journal of Science and Research, 4, 3, 1473-1475.

Asifa, K. P., Chitra, K. C. (2016a): Alteration in hepatic antioxidant defence system induced by nonylphenol in cichlid fish, Etroplus maculatus (Bloch, 1795). Journal of Zoology Studies, 3, 4, 30-38.

Asifa, K. P., Chitra, K. C. (2016b): Impact of nonylphenol on antioxidant system and acetylcholinesterase activity in the brain of Etroplus maculatus (Bloch, 1795). International Journal of Research, 3, 13, 114-123.

Asifa, K. P., Vidya, P. V., Chitra, K. C. (2016a): Chlordeconeinduced changes in muscular antioxidant system of cichlid fish, Etroplus maculatus (Bloch, 1795). International Journal of Research, 3, 1, 21-29.

Asifa, K. P., Vidya, P. V., Chitra, K. C. (2016b): Genotoxic effects of chlordecone in the cichlid Fish, Etroplus maculatus (Bloch, 1795) using micronucleus test. Research Journal of Recent
Sciences, 5, 8, 16-20

Bahner, L. H., Wilson, A.J., Sheppard, J.M., Patrick, J. M., Goodman, L. R., Walsh, G. E. (1977): Kepone ${ }^{\circledR}$ bioconcentration, accumulation, loss, and transfer through estuarine food chains. Chesapeake Science, 18, 3, 299-308.

Bakde, C., Poddar, A. N. (2011): Effect of steel plant effluent on acid and alkaline phosphatases of gills, liver and gonads of Cyprinus carpio Linn. (1758). International Journal of Environmental Sciences, 1, 6, 1305-1316.

Bandyopadhyay, U., Das, D., Banerjee, R. K. (1999): Reactive oxygen species: Oxidative damage and pathogenesis. Current Science, 77, 5, 658-666.

Bessey, O. A., Lowry, O. H., Brock, M. J., Lofez, J. A. (1946): The determination of vitamin $A$ and carotene in small quantities of blood serum. The Journal of Biological Chemistry, 166, 1, 177188.

Carlberg, I., Mannenvik, B. J. (1985): Purification and characterization of the flavoenzyme glutathione reductase from rat liver. The Journal of Biological Chemistry, 250, 14, 5474-5480.

Castro, L., Freeman, B. A. (2001): Reactive oxygen species in human health and disease. Nutrition, 17, 2, 163-165.

Chandra, S., Banerjee, T. K. (2004): Histopathological analysis of the respiratory organs of Channa striata subjected to air exposures. Veterinary Arhives, 74, 1, 37-52.

Chang, J. C., van der Hoeven, L. H., Haddox, C. H. (1978): Glutathione reductase in the red blood cells. Annals of Clinical and Laboratory Science, 8, 1, 23-29.

Chitra, K. C., Sajitha, R. (2014): Effect of bisphenol A on the antioxidant defence system and its impact on the activity of succinate dehydrogenase in the gill of freshwater fish, Oreochromis mossambicus. Journal of Cell and Tissue Research, 14, 2, 4219-4226.

Chitra, K. C., Sr Maiby (2014): Oxidative stress of bisphenol-A and its adverse effect on the liver of freshwater fish, Oreochromis mossambicus. International Journal of Scientific Research, 3, 7, 221-224.

Claiborne, A. (1985): Catalase activity. pp. 283-284. In: Greenwald, R. (eds.), CRC Handbook of methods for oxygen radical research. CRC Press, Boca Raton, Florida.

Dorval, J., Hontela, A. (2003): Role of glutathione redox cycle and catalase in defense against oxidative stress induced by endosulfan in adrenocortical cells of rainbow trout (Oncorhynchus mykiss). Toxicology and Applied Pharmacology, 192, 191-200.

Dyhrman, S. T., Palanik, B. (1999): Phosphate stress in cultures and field populations of the dinoflagellate prorocentrum minimum detected by single-cell alkaline phosphatase assay. Applied and Environmental Microbiology, 65, 7, 3205-3212.

Ellman, G. L., Courtney, K. D., Anders, V., Featherstone, R. M. (1961): A new and rapid colorimetric determination of acetylcholinesterase activity. Biochemical Pharmacology, 7, 2, 88-90.

Halliwell, B. (1995): Antioxidant characterization. Methodology and mechanism. Biochemistry and Pharmacology, 49, 1341-1348.

Halliwell, B., Gutteridge, J.M.C. (1999): Free radicals in biology and medicine, 3rd ed, Clarendon Press; New York : Oxford University Press, Oxford. 
Hayat, N. M., Sabullah, M. K., Shukor, M. Y., Syed, M. A., DahaIan, F. A., Khalil, K. A., Ahmad, S. A. (2014): Effect of pesticides on cholinesterase activity by using fish as a biomarker. Nanobiology Bionanotechnology, 1, 17-25.

Jaishankar, M., Tseten, T., Anbalagan, N., Mathew, B. B., Beeregowda, K. N. (2014): Toxicity, mechanism and health effects of some heavy metals. Interdisciplinary Toxicology, 7 , $2,60-72$.

Jin, Y., Zhang, X., Shu, L., Chen, L., Sun, L., Qian, H., Liu, W., $\mathrm{Fu}, \mathrm{Z}$. (2010): Oxidative stress response and gene expression with atrazine exposure in adult female zebrafish (Danio rerio). Chemosphere, 78, 7, 846-852.

Kavlock, R. J., Chernoff, N., Rogers, E., Whitehouse, D. (1980): Comparative tissue distribution of mirex and chlordecone in fetal and neonatal rats. Pesticide Biochemistry and Physiology, 14, 3, 227-235.

Lafontaine, A., Gismondi, E., Lecomte, C. B., Geraudie, P., Dodet, N., Caupos, F., Lemoine, S., Lagadic, L., Thomea, J. P. and Leray, J. F. (2016): Effects of chlordecone on 20-hydroxyecdysone concentration and chitobiase activity in a decapod crustacean, Macrobrachium rosenbergii. Aquatic Toxicology, 176, 53-63.

Landrum, P. F., Fisher, S. W. (1999): Influence of lipids on the bioaccumulation and trophic transfer of organic contaminants in aquatic organisms, pp. 203-234. In: Arts, M. T., Wainman, B. C. (eds.). Lipids in freshwater ecosystems. Springer-Verlag, Inc., New York.

Li, S., Tan, H. Y., Wang, N., Zhang, Z. J., Lao, L., Wong, C. W., Feng, Y. (2015): The Role of oxidative stress and antioxidants in liver diseases. International Journal of Molecular Sciences, 16, 11, 26087-26124.

Li, Z. H., Zlabek, V., Velisek, J., Grabic, R., Machova, J. and Randak, T. (2010): Modulation of antioxidant defence system in brain of rainbow trout (Oncorhynchus mykiss) after chronic carbamazepine treatment. Comparative Biochemistry and Physiology, Part C, 151, 137-141.

Lowry, O. H., Rosebrough, N. J., Farr, A. L., Randall, R. J. (1951): Protein measurement with the Folin phenol reagent. The Journal of Biological Chemistry, 193, 1, 265-275.

Lushchak, V. I. (2011): Environmentally induced oxidative stress in aquatic animals. Aquatic Toxicology, 101, 1, 13-30.

Marklund, S., Marklund, G. (1974): Involvement of superoxide anion radical in antioxidation of pyrogallol and a constituent assay for superoxide dismutase. European Journal of Biochemistry, 47, 3, 469- 474.

Mates, J. M., Gomez, Perez-Gomez, C., Castro, I. N. D. (1999): Antioxidant enzymes and human diseases. Clinical Biochemistry, 32, 8, 595-603.

Migliore, L., Coppede, F. (2009): Environmental-induced oxidative stress in neurodegenerative disorders and aging. Mutation Research, 674, 1-2, 73-84.

Mishra, A., Poddar, A.N. (2014): Acute toxicity and behavioral response of the food fish Channa punctatus (Bloch) to an insecticide dichlorvos. Journal of Industrial Pollution Control, 30, 2, 219-222.

Murthy, K. S., Kiran, B. R., Venkateshwarlu, M. (2013): A review on toxicity of pesticides in Fish. International Journal of Open Scientific Research, 1, 1, 15-36.

Ohkawa, H., Ohishi, N., Yagi, K. (1979): Assay for lipid peroxidation in animal tissues by thiobarbituric acid reaction. Analytical Biochemistry, 95, 2, 351-358.

Patil, V. K. M., David, M. (2009): Hepatotoxic potential of malathion in the freshwater teleost, Labeo rohita (Hamilton). Veterinarski Arhiv, 79, 2, 179-188.

Perry, S. F., Laurent, P. (1993): Environmental effects on fish gill structure and function. pp. 231-264. In: Rankin, J. C., Jensen, F. B. (eds), Fish Ecophysiology, Chapman and Hall, London. 9.

Pick, E., Keisari, Y. (1981): Superoxide anion and $\mathrm{H}_{2} \mathrm{O}_{2}$ production by chemically elicited peritoneal macrophages-induced by multiple nonphagocytic stimuli. Cellular Immunology, 59, 2, 301-318.

Rejitha, R., Asifa, K. P., Chitra, K. C. (2016): Induction of reactive oxygen species in brain of Etroplus maculatus after exposure to bisphenol A. Journal of Applied and Natural Sciences, 8, 1, 386-391.

Sevcikova, M., Modra, H., Slaninova, A., Svobodova, Z. (2011): Metals as a cause of oxidative stress in fish: a review. Veterinarni Medicina, 56, 11, 537-546.

Sitaramaraju, S., Prasad, N.V.V.S.D., Reddy, V. C., Narayana, E. (2014): Impact of pesticides used for crop production on the environment. Journal of Chemical and Pharmaceutical Sciences, 3, 75-79.

Srivastava, P., Singh, A. (2014): Behavioral changes by inhibition of acetylcholinesterase induced by Trizole (Propiconazole) fungicide on freshwater fish Clarias batrachus. World Journal of Fish and Marine Sciences, 6, 1, 82-86.

United Nations Environment Programme (UNEP) (2007): UNEP/ POPS/POPRC.3/20/Add.2, Chlordecone risk management evaluation. Stockholm convention on Persistent Organic Pollutants Review Committee Third meeting Geneva, 19-23 November 2007.

Varo, I., Navarro, J. C., Amat, F., Guilhermino, L. (2003): Effect of dicholorvos on cholinesterase activity of the European sea bass (Dicentrarchus labrax). Pesticide Biochemistry and Physiology, 75, 3, 61-72.

Vidya, P. V., Chitra, K. C. (2015): Elevation of reactive oxygen species in hepatocytes of tilapian fish when exposed to silicon dioxide: A potential environmental impact of nanomaterial. International Journal of Recent Scientific Research, 6, 3, 2990-2995.

Wilhelm, F. D. (1996): Fish antioxidant defences - a comparative approach. Brazilian Journal of Medical and Biological Research, 29, 12, 1735-1742.

Yang, L., Zhou, B., Zha, J. and Wang, Z. (2016): Mechanistic study of chlordecone-induced endocrine disruption: Based on an adverse outcome pathway network. Chemosphere, 161,372-381. 